\title{
Berimbau's "use value" and "exchange value" Production and consumption as symbols of freedom in contemporary global Capoeira Angola
}

Celso de Brito (UFRGS)

\begin{abstract}
This article approaches the historical transformations surrounding the use of the berimbau - a musical instrument of African origin, which became Capoeira's greatest symbol - and the relation between this process with the history of the Afro-Brazilian population. In the perspective of the Anthropology of Economics, the berimbau is analyzed from the beginnings of its presence in Brazil taking into account the relation between production and consumption, leading to the examination of its insertion in the international market. The argumentation is based on data collected between 2008 and 2010 in the Brazilian cities of Curitiba and Salvador; in the French cities of Lyon, Grenoble and Montelimar; and in the Spanish city of Santiago de Compostela. Specialized websites were also used as reference. The article suggests that the berimbau would symbolize the different meanings of freedom corresponding to the demands of the Afro-Brazilian population in several historical contexts, either as a religious fetish, as a working tool or even as merchandise. It is also suggested that the search for freedom in the AfroBrazilian social segment is still in course nowadays, though inserted in the context of the international market in which the berimbau and the practice of Capoeira Angola that associates with it become merchandises, and, as such, a means of acquiring a specific type of freedom: the freedom of consumption.
\end{abstract}

Keywords: Berimbau - Capoeira - Consumption - Freedom 


\section{Berimbau's "use value" and "exchange value" Production and consumption as symbols of freedom in contemporary global Capoeira Angola'}

Celso de Brito (UFRGS)

\section{Introduction}

According to Shaffer (1977) the berimbau is a chord instrument from the category of the sitar. Of African origin, it was brought to the Southern and Central Americas with the beginning of the slave trade. The connection between the berimbau and Capoeira took place towards the end of the 19th century. By the $2 \mathrm{O}^{\text {th }}$ century, the instrument had become a symbol of Capoeira. Capoeira is a fight or game between two people that takes place in the center of a circle formed by other players (called "roda"). The player's body movements are performed according to the rhythm given by the berimbau. The instrument is so essential for the practice that it was considered by one of the most famous Capoeira Masters as the "one true Capoeira Master"2 (Master Pastinha, 1968).

As Neiburg states (2010), the Anthropology of Economics is an endeavor that requires ethnographic work. Rather than regarding economic phenomena from previous theoretical conceptions, one must search for

$[\ldots]$ the meanings that the semantic field that surrounds economics possesses

1 This article was first written as an end of term paper for the discipline of Economic Anthropology given by Professors Rubem George Oliven and Ariel Sander Damo at the Post Graduate Program in Social Anthropology, Federal University of Rio Grande do Sul. I thank these professors, the anonymous evaluators and professor Peter Fry for their comments and suggestions.

2 Master Bimba was a deeply acknowledged berimbau player and contributed considerably to the world propagation of the musical value of the instrument when he played with Charlie Byrd's jazz group. However, in his efforts to institutionalize Capoeira in the 1930's, he reduced the set of instruments then used in the "rodas" (consisting of more than one berimbau, atabaque, reco-reco, agogô, pandeiros and even violas and ganzás) to a berimbau and two pandeiros only, diminishing, thus, the harmonic richness of the berimbau's set. Master Pastinha, on the other hand, institutionalized Capoeira Angola with a drum set formed by two pandeiros, agogô, reco-reco and atabaque plus three berimbaus, valuing this set a great deal. The berimbaus has been understood as the materialization of Capoeira Angola's sacredness, as a consequence of the discourse of Masters that assign to this three-berimbaus structure the same sacredness that is attributed to the three atabaques of the African-roots religion, the Candomblé. This turns berimbau into a religious instrument inserted in the "lineage system of the transnational Capoeira Angola" (see Brito and Lewgoy, 2012). For this reason, this paper focuses the role of the berimbau for Capoeira Angola groups. 
in the interaction of agents with different characteristics and scales, as people, groups or nations (Neiburg 2010: 3).

Starting from Daniel Miller's proposals in "Material Cultures: why some things matter?" (1992), I choose as the focal point of my analysis the berimbau as "material culture". The idea of "material culture" found in Miller does not restrict the objects that may be approached according to this perspective, but states that the core of this type of approach is to understand the relation of the artifacts with the social context in which they are produced and consumed. It is a construction determined by the specificity of the theme to be researched.

In the introduction of "The social life of things" (Appadurai 2008) Appadurai argues that the social life of an object is related to specific situations in which it participates. This phenomenon is closely related to the exchangeable nature of things. Kopytoff (2008) assigns this condition of the "exchange object" to the process of "commodification" of the objects that characterize contemporary capitalism.

By analyzing the cultural biography of an object in such a way, one is able to comprehend the social relations that come into being between individuals and objects, in particular, their production and consumption. This requires a study of the history of the object in question, considering specific periods and the respective socio-cultural contexts through it object is valued in different ways and "singularized" many times throughout its social life (Kopytoff 2008).

Miller (2007) shows that most studies about consumption are limited, in the sense that present themselves as heirs to a conception of consumption that refers to the idea that consumption involves the destruction of material culture. They see consumption as

[...] a danger to both society and the environment. As such mass consumption has been regarded more as an evil than as the good. There has been very little acknowledgment of the degree to which the rise of mass consumption could also be seen as synonymous with the abolition of poverty (Miller 2007: 34).

In general, I believe that another product of consumption is that it has a bearing on citizenship, in two ways: 1 ) from the moment in which the choice of the product to be consumed presents itself as an option guided by the conscience that this action has social and environmental consequences; 2) the increase in consumption allows subjects to participate in the sphere of the market enjoying the goods produced by society. 
In this article, I present the data collected in a multi-sited ethnography (Marcus 1995), performed between 2008 and 2010 in Brazil (Curitiba and Salvador), France (Lyon, Grenoble and Montelimar) and Spain (Santiago de Compostela). I also include data Internet sites and blogs related to Capoeira. By looking at the history of the berimbau form the $19^{\text {th }}$ century to the present day, I will argue that as a religious fetish, a tool or a commodity, the berimbau carries different meanings of freedom that inspired the men who produced it in the past and who produce it and play it today.

\section{The Berimbau as "use value"}

Based in Portuguese chronicles about Africa from the 1880s, Shaffer (1977) affirms that the berimbau originated in the Congo/Angola region, where it was called humbo, rucumbo, violam, or still, lucungo (Shaffer 1977: 6-9).

With the exception of a text by Ignaz Von Olfers (1818), found by Oliveira Pinto (2001) in the Museum of Anthropology of Berlim, where the German author describes the characteristics of an instrument he found in Brazil with the name of cunga, the only documents about the berimbau in this period are images, such as the photograph of Marc Ferrez in the second half of the $19^{\text {th }}$ century and two paintings by Debret from 1826: in one of them there is a black man playing berimbau, surrounded by women carrying baskets on their heads; in the other, we see a black man playing berimbau next to another black man who holds a basket in his hands.

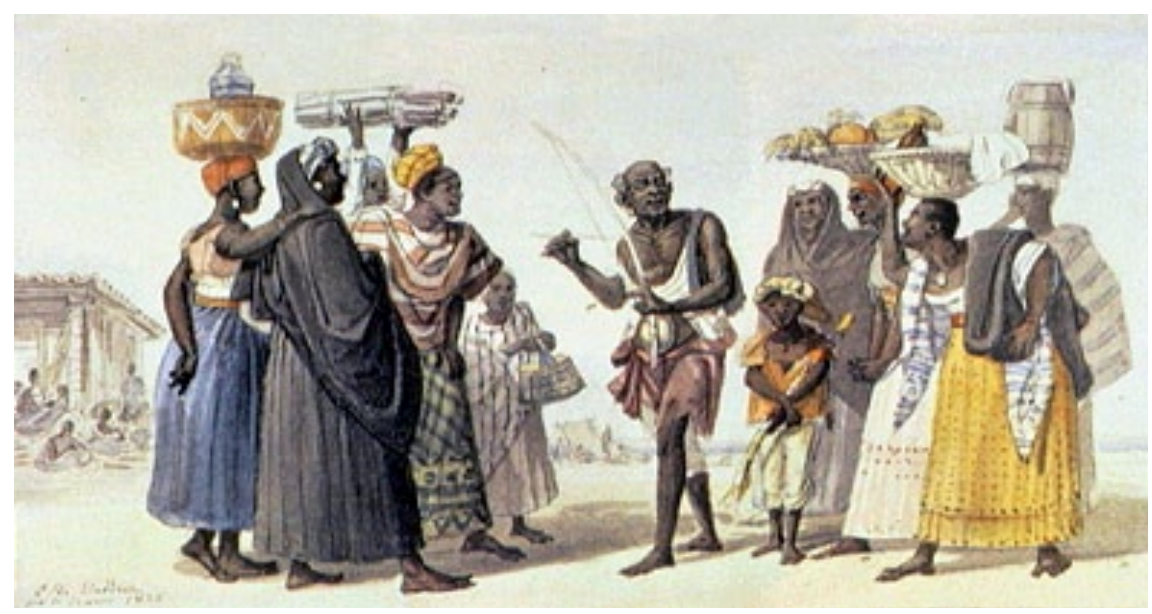

Berimbau's player (Debret, 1826) 


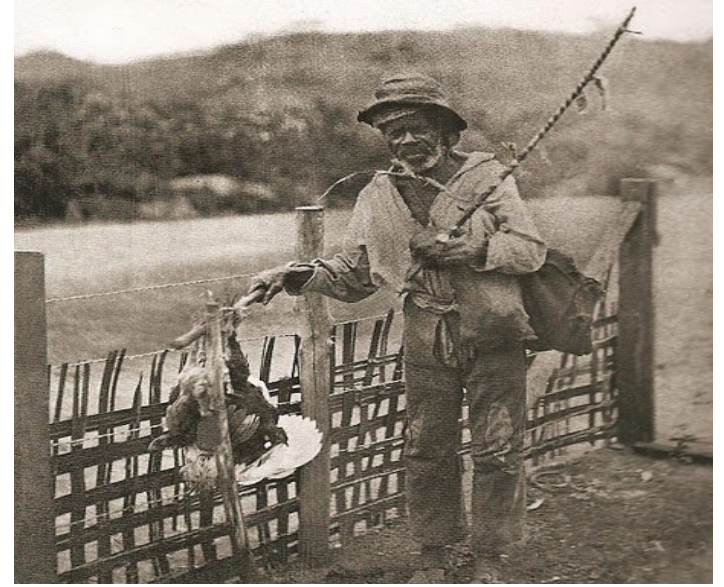

Black man and the berimbau (Photograph by Marc Ferrez, second half of the $19^{\text {th }}$ century)

These, together with other paintings by Debret and Rugendas that portrait Capoeira being performed with drums only, seem to point to the fact that before being used in Capoeira, the berimbau was used commercially by "negros de ganho" (slaves who traded small goods or performed services for a payment, that was shared with their owner) as a way to call the attention of potential buyers to their products.

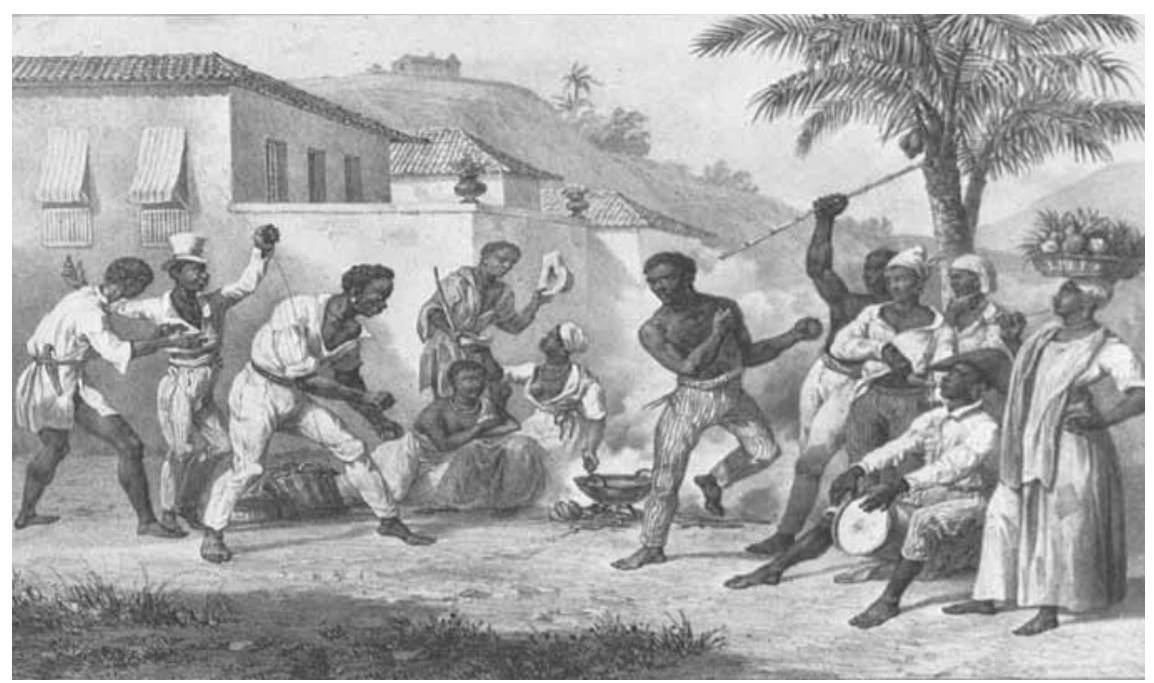

Capoeira (Rugendas 1830) 
The documents about the berimbau in the $19^{\text {th }}$ century in Brazil describe it as a wooden arc, to which was attached a gourd, which serves as a resonance box. The instrument was played with a think stick, different notes being produced by the pressure of the fingers on the string. However, in 1958, Almeida published a text describing the use of a coin (the "dobrão de 40 réis") being used to apply pressure to the string.

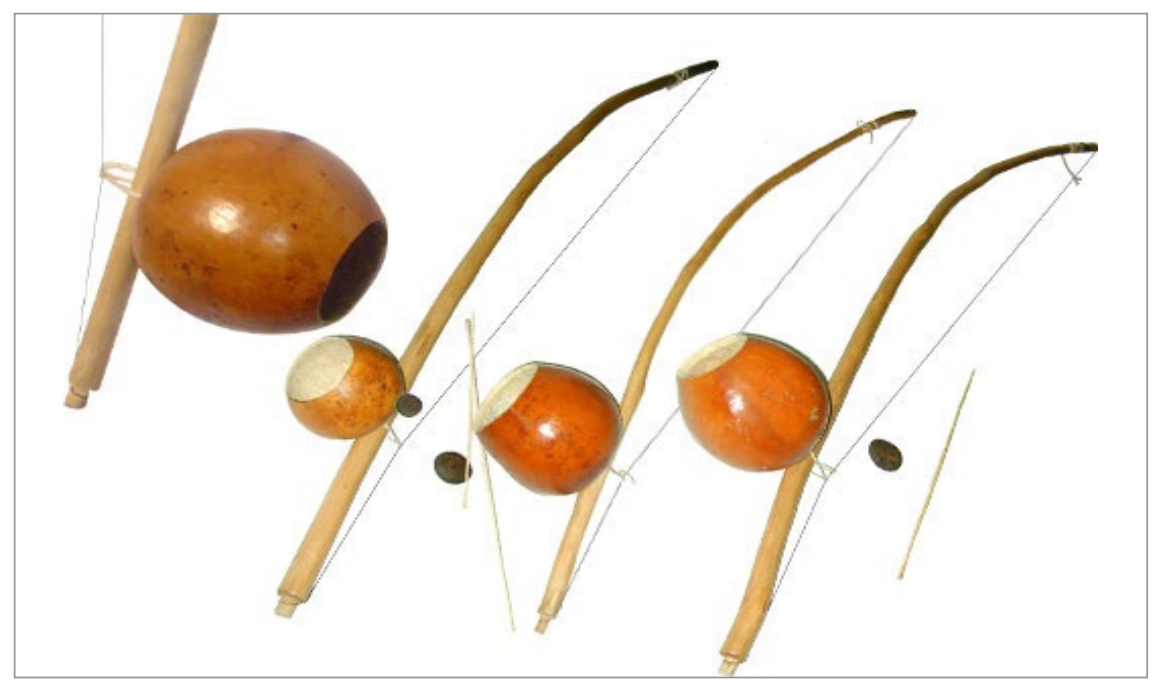

Contemporary berimbau, baquetas (sticks) and dobrões

As I have pointed out elsewhere (Brito 2011) freedom for the blacks at the beginning of the $19^{\text {th }}$ century was confined to the spiritual sphere, since it seemed impossible in the secular world. This was due in part to the Catholic Church's strategy of giving prominence to black saints such as Saint Benedict and Saint Anthony of Categeró as ideal models of conduct for black people, who should accept the condition of slavery as a natural condition for men and women of black skin. As a reward for such resignation, like these saints, they would ultimately find eternal freedom in the Kingdom of God. (Santana 2007).

By the end of the $19^{\text {th }}$ century, the members of the newly formed Brotherhoods of Black Men started to manage the treasuries of their churches, which had previously been controlled solely by white men. Part of the money raised was used to set free enslaved blacks. By the same token, blacks who were able to work for their owners in the street and keep part of the money (the "negros de ganho") began to see currency as an object of desire, not for its value in itself, but because it represented the possibility of buying real 
freedom and of buying one's own work force with the possibility of having the freedom to sell it on the labor market.

For these negros de ganho, the berimbau was an instrument of leisure and for work. The negros de ganho with their berimbau at hand were found in the streets. In their leisure time they relaxed in "playing" the elaborate movements of Capoeira. In this way, the berimbau became associated with the dance/fight of Capoeira. According to Shaffer (1977) the association of Capoeira and the berimbau was completed by the end of the $19^{\text {th }}$ century.

In Rio de Janeiro, the Black Guard (Guarda Negra) emerged - an army of blacks who played Capoeira and defended the Monarchist Party which was seen as responsible for the abolition of slavery on May $13^{\text {th }}, 1888$. In 1889 , Brazil became a Republic. In its 1891 Constitution Capoeira was defined as a crime and was heavily repressed. Even though Capoeira in Bahia was more playful that its counterpart in Rio de Janeiro, the Capoeira players in the city of Salvador also suffered from police repression and used their berimbaus as weapons, attaching a small razor blade to its extremity, as Master Pastinha reports in his record 3 .

Thus, one could affirm that until the beginning of the 2oth century, the berimbau was used in different ways: as a work tool, an instrument of leisure or even as an apparatus for self-defense.

\section{The Berimbau as "exchange value"}

The practice of Capoeira only began to be legal during the 1930's with Master Bimba's Capoeira Regional. In 1942 Master Pastinha devised a different form of Capoeira denominated Capoeira Angola (for the relation between Capoeira and the construction of Brazilianness and the imagined Africa see Brito 2008). In that year, the currency called Real went out of circulation and the dobrão lost all of its financial value, being replaced by the Cruzeiro. Authors such as Santos (2005) have shown that Capoeira ceased to be associated only with malandragem - a Bohemian lifestyle associated with idleness and hustling of one kind another to take its place as a tourist attraction. Capoeira began to be commercialized and Masters were hired by the State or by hotels to make

3 "Mestre Pastinha: eternamente": CD digitally remastered and distributed by Praticando Capoeira magazine, ano 1, n. 4. São Paulo: Editora D+T, 2001. 
"Rodas de Capoeira" as a tourist attraction in the city of Salvador. Santos argues that in this way the State and the market began to exert a subtle control of Capoeira and the capoeiristas.

In that same year of 1942, the berimbau started to be commercialized at the Mercado Modelo (located in the neighborhood called Cidade Baixa in the city of Salvador). To this day it displays the greatest number and variety of berimbaus.

According to Shaffer (1977), it was Master Waldemar Rodrigues da Paixão (or Walldemar da Pero Vaz, or even Waldemar da Liberdade 4- "of Freedom") who started selling berimbau in the Mercado Modelo. It was his major source of livelihood until his death in 1990 (Abreu 2003). Unfortunately, Shaffer (1977) wasn't interested in knowing (or at least didn't write about) the manufacture and sale price of the berimbau when it first came on to the market. In spite of this omission, he offers valuable information about the manufacture and sale prices of the berimbau in 1977 and also tells us that ordinary ferrules were offered to the buyers, instead of the dobrão.

The fact that Master Waldemar was known as one of the best players and singers of Capoeira among the Capoeira Masters in Salvador, gave enormous credibility to the berimbau he built. According to Shaffer (1977) the cost of producing the berimbau was about $\mathrm{Cr} \$ 20$ to $\mathrm{Cr} \$ 25$. It could be sold for twice or three times as much.

In this way, the berimbau, whose value was determined by its use, became merchandise in the beginning of the 1940's. It was turned out in series (around a hundred pieces a week). The original medals or dobrões used to pressure the string were replaced by a sort of washer. The berimbau was no longer associated with the fight for freedom. The use of a common washer represented the transformation of an object valued by its "use" to an object valued for its "exchange": the production of the berimbau began to be thought of in terms of the maximization of profit. If the berimbau had signified liberty to the slaves who played it, but the 1940s, it was just one more commodity in the capitalist order.

Nowadays berimbaus are sold through the Internet. Valmir das Biribas is a leading player in the market due to the acknowledgment of the quality of

4 Liberdade is a densly populated popular suburb of Salvador, home to some of the most important institutions related to black culture in the city. 
the instruments he sells. He is presented by foreign berimbau sale websites as an heir to Master Waldemar's manufacturing techniques. His fully equipped berimbau, complete with the playing stick (baqueta), the dobrão, and caxixi are sold for an average of 90 Euros on the European market. (http://www.ocapoeira.com/fr/c-2o-berimbau ${ }^{5}$.)

To have an idea of the difference between berimbau prices in 1977 and 2011 we can compare berimbau values with the Dollar price in each period.

In 1977 a berimbau cost about US $\$ 1,5$ to build, and was sold for US $\$ 4$. In 2011 a berimbau costs less than US $\$ 15$ to build and is sold for US $\$ 90$ on the international market6. If the buyer wants the complete apparatus, the caxixi (an instrument of African origin that resembles a rattle, made with vine and seeds) will cost another US\$20, the dobrão US $\$ 12$ and the sticks US\$8. This gives a total value of US\$130 (http://www.ocapoeira.com/fr/c-20-berimbau).

In 34 years, the difference between the cost of production and market price for each berimbau sold, increased from US\$2,5 to US\$115. In 1977, the craftsman's work for each berimbau sold was 3,79\% of the minimum wage of the time (US\$66). The same work is nowadays is worth $40 \%$ of a minimum wage, now worth US\$347.

If based on the Dollar's purchase power, the craftsman's work increased in value by $5000 \%$.

The number of berimbaus currently produced in Brazil is not known for sure. But it is known that the international demand for the berimbaus is threatening to exhaust supplies the biriba (Eschweilera ovata), the wood used to make it, as stated in this document released by Brazil's Ministry of Culture:

The concern about the biriba's sustainability and management is mostly due the internationalization of Capoeira, which has increased the demand for the berimbaus. The demand for the instrument has generated the need for sustainable exploitation of the raw materials used in its building (http://www.encontrosprocapoeira.org.br/arquivos/capoeira_e_Politicas_de_Desenvolvimento_ Sustentavel.pdf).

5 It is long gone the time in which a Brazilian artisan could easily sell a "broomstick berimbau" (a really bad berimbau, made of inadequate wood) to unwary tourists as a souvenir from Bahia, as Abreu (2003) suggests Master Waldemar would do.

6 The prices of the products are originally in Euros, here converted to Dollar. The exchange rate used is 1 Euro $=1,3$ o Dollars. 


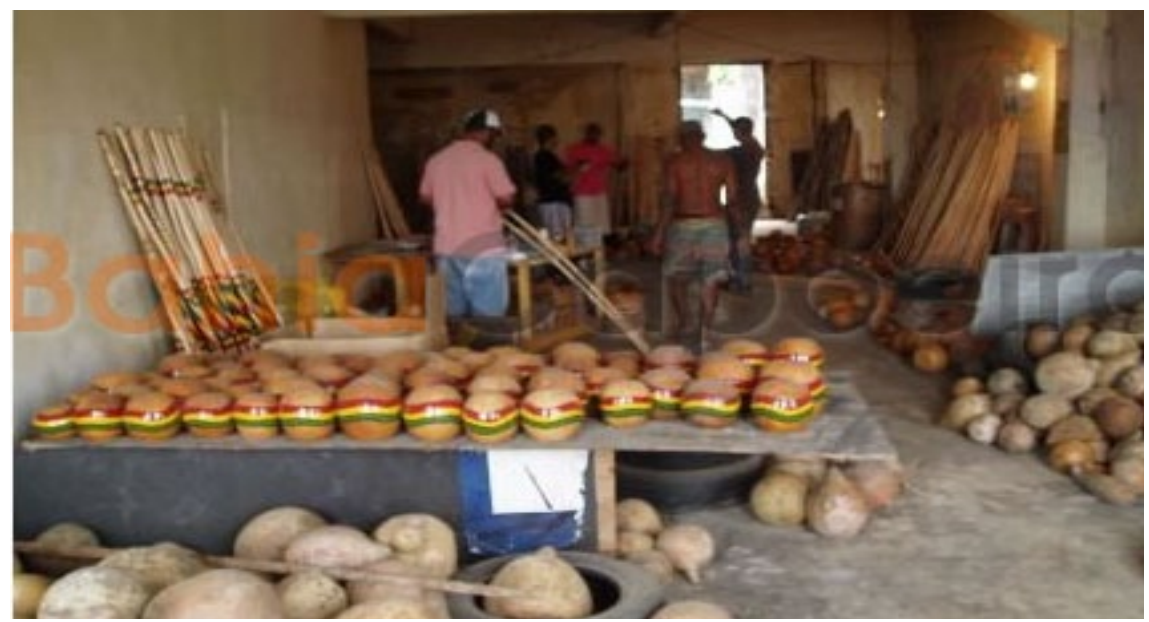

Valmir das Biribas atelier in Salvador

On an American site (http://bahia-capoeira.com/blog/2008/o1/interviewwith-valmir-das-biribas-part-1/\#more-244) about Capoeira I found an interview (by Álvaro Letelier Hidalgo) with Valmir das Beribas in which he is asked about the effects of this international trade on Capoeira and the craftsman:

Hidalgo: And regarding these thin berimbaus that are being sold these days, it's a case of supply and demand, because the foreigners are buying them. Does this ultimately help or hurt craftsmanship and Capoeira?

Valmir: On one hand it helps, on the other hand it hurts. It's a double-edged sword. Because it's part of Capoeira's evolution, but at the same time it's destroying many things - like the originality, the craftsman making the instrument with love, and not for money. But money is the driving force behind everything. But I also think it's important for the survival of the trade. Like I said, it's a balance, with a good side and a bad side. A little bit of the soul, the essence, the roots that the ancestors left for us, are lost. And we end up losing out a little bit because of money.

According to Valmir das Biribas the commodification of the berimbau, has positive and negative consequences. While he acknowledges that the money earned is important for the very existence of the craft, he fears the risk of losing the traditional knowledge left by the Capoeira's ancestors. Traditional social relations, he fears, will be affected by the commodification of the berimbau and by the modernization of its production. 
The change in the production of the berimbau noted by Valmir das Biribas is real. The craftsmanship of the past has given way to semi-industrialized process of production in series, as we see at another berimbau sales site:

The centuries-old instrument gets a modern touch to make part of the globalized world. To admit the evolution without losing the essence is to break the barriers of time with wisdom. Produced in a serial semi-industrialized process, our berimbau is made with recycled and IBAMA-certified wood and committed to the "Green Label" recognized by consumers and producers. Our product is made with new resources, such as a tuning peg and a better fixation of the resonance box, with an electrical output (http://www.berimbausecologico.com.br/).

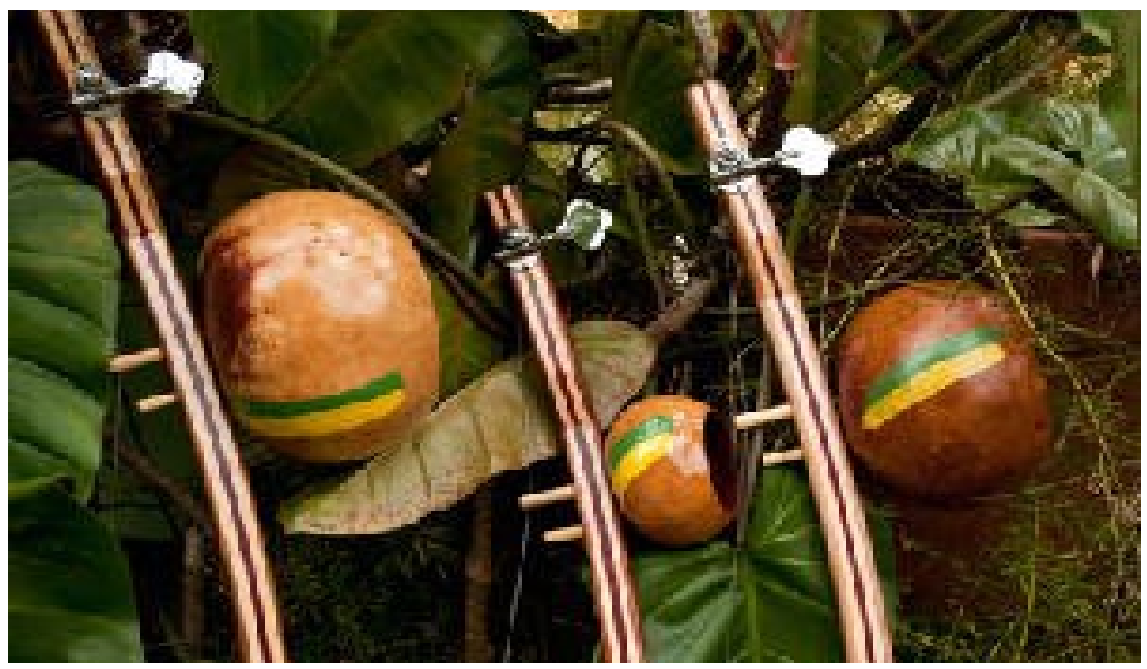

The ecological berimbau

\section{Social relations and money in the contemporary Capoeira Angola}

Although there is a strong urge towards industrialization in berimbau building that has been exacerbated by growing demand from the foreign market, the craftsman berimbau made by Valmir das Biribas are among the most valued in the market. This is due to the high value foreign consumers attribute to articles whose process of production is associated to the idea of "traditional culture".

The dobrão once used in the berimbau became a collector's artifact; the use of the common washer has now also been abandoned. During the 1980s, a 
copper-colored metal plate the same size of the original dobrões started to be commercialized in the along with the berimbau.

There seems to have been, in this period, a synthesis between the need for profit, and, therefore, the use of accessible materials, and the symbolism of the dobrão associated to a mystique of the medal, since some Masters sent their dobrões to be blessed by priests from Candomblé, just as they had done with the São Bento medal. They are still careful not to lend their dobrões, to avoid the risk of losing the protection that they bring.
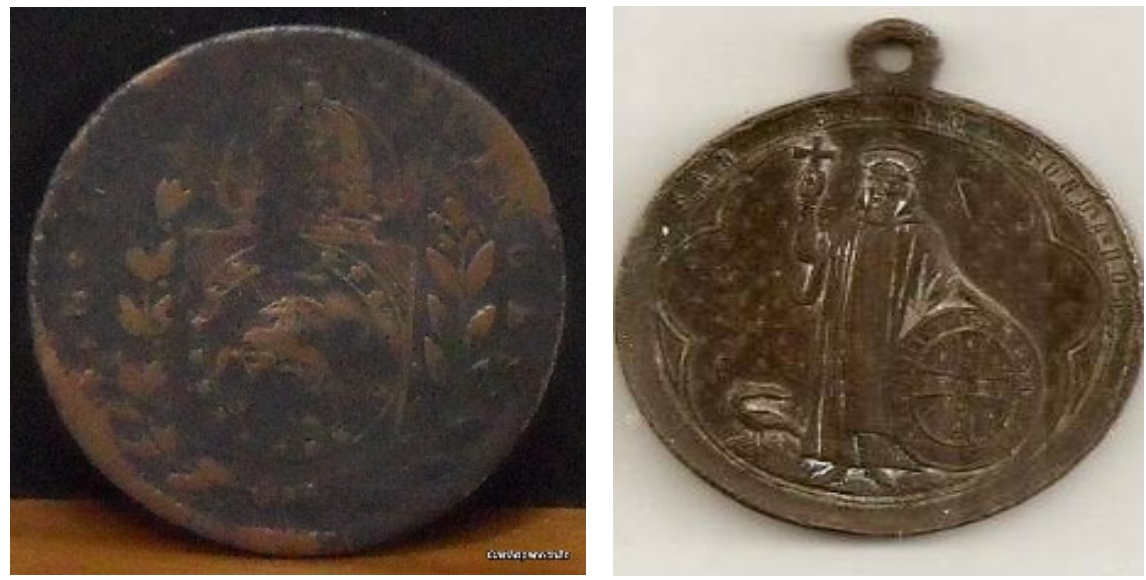

Dobrão (40 Réis) São Bento medal

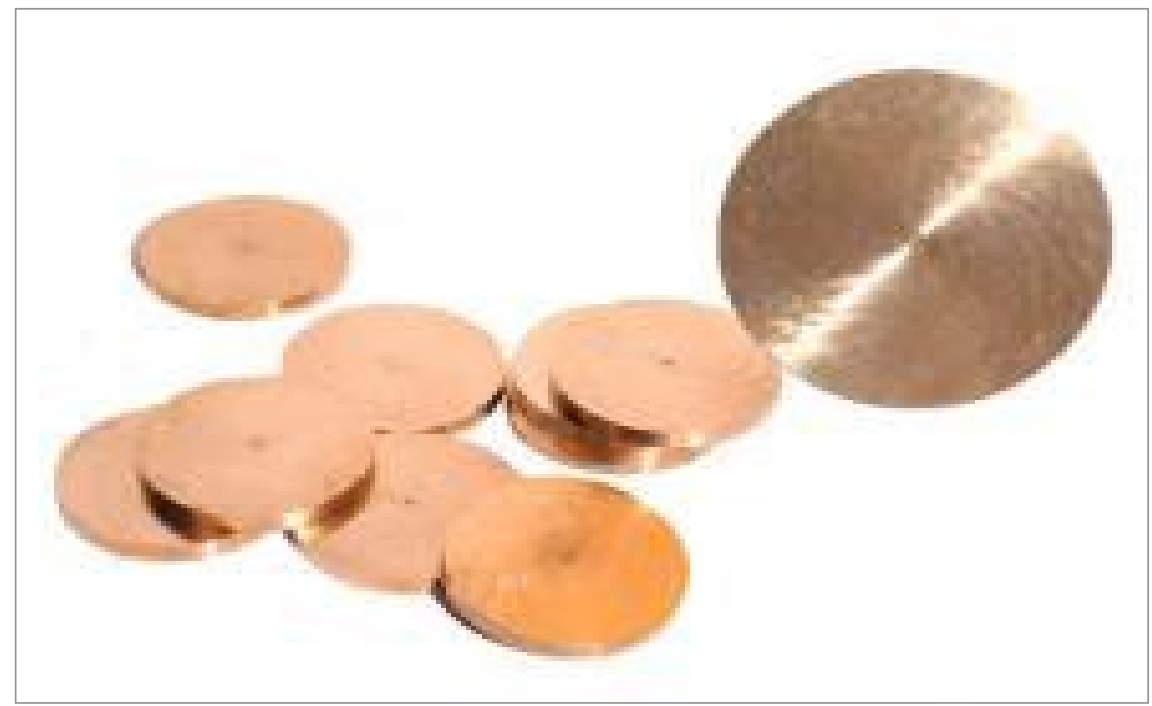

“Dobrão" sold at 8,9 Euros each (http://www.ocapoeira.com/fr/494-dobrao-de-bronze.html). 
I believe that a possible interpretation of this process of valuing is close to what Heinich (1991) called "the fetish of the Master's name".

It is through the discourse of connection between Master Valmir das Biribas and the traditional method inherited from Master Waldemar das Paixões that his products are valued in the international market, as pointed earlier. http://www.ocapoeira.com/fr/78-berimbau-valmir-biriba.html:

Valmir das Biribas a reçu son enseignement de la fabrication de berimbau en travaillant avec son père aujourd'hui disparu. Il se concentre de façon exclusive sur la fabrication de cet instrument qui le passionne depuis son enfance où il vivait à Ilha de Maré.

Il est accompagné dans sa profession par Chupa Molho qui travaillait déjà avec le père de Valmir. Chupa molho est un expert dans la préparation du berimbau, il a fréquenté Waldemar da Paixão quand il était gamin et a connu une Capoeira authentique, d'une autre époque. (my emphasis)'

Heinich (1991) describes the process through which Van Gogh's works are currently valued due to an anachronistic feeling of guilt over the fact that the artist was not recognized during his life, and, therefore lived in misery. Heinich (1991) argues that the immense value attributed to Van Gogh's works is a way for society to find redemption for the neglect that the artist suffered during his life.

In the case of Valmir das Biribas, his traditional knowledge, associated with a story of suffering from a black man in a Latin American country, together with the connection between his technique in the manufacturing of the berimbau and the technique used by Master Waldemar da Paixão, which makes of Valmir das Biribas's berimbau a unique product in the global market, associated as it is with the poverty of Valmir das Biribas and the fetish of the name of a Master who is now revered but who was not recognized in his lifetime, Master Waldemar da Paixão.

It is well known among the capoeiristas in Brazil and in France that, like Master Pastinha and Master Bimba, Master Waldemar da Paixão died in misery and suffering.

7 It was not possible to find out the nature of the relation between the virtual shop "capoeiraboutique" and Valmir das Beribas. There is significant possibility of it being a mere European middleman that buys the berimbau for 15 dollars and sells them for 130 dollars. However, that possibility doesn't revoke the argument here considered regarding the mobilization of victimization discourses and of the connection between Valmir das Biribas and Master Waldemar. 
In the 1980's, Master Pastinha declared to the newspaper "A Tarde" of Salvador (Abreu 2003: 15) "Capoeira needs nothing. I'm the one who needs". The following year, 1981, that marked his death, he declared:

The Capoeira from Bahia is high in the "market", while the most important Masters that keep that tradition, such as myself, are dying in extreme poverty (in: Abreu 2003:14).

To try to avoid these tragic ends that victimized Capoeira Masters in the past, a group of people organized through the Internet (at the Orkut community called "Mestre Pastinha") have researched Master Waldemar da Paixão's berimbaus songs that were recorded in 1951 by Anthony Leeds and can be found in the archive of the University of Indiana. The songs were edited and put together with testimonials from the Master in a CD called "Master Waldemar - I sang the Capoeira", which was commercialized with the objective of raising money to help Master Bigodinho (a disciple of the late Master Waldemar da Paixão) who was ill and in extreme poverty. Master Bigodinho died on April $4^{\text {th }}, 2011$.

The project "Master Waldemar da Paixão for Master Bigodinho" has its own website, (http://sites.google.com/site/campodemandinga/). To dissipate possible doubts over the bona fides of the site, it shows on a map of the world the places where the CDs have been sent, complete with the accounts and statistics of the project, including the receipts signed by Master Bigodinho.

During the year 2010, the project raised and transferred to Master Bigodinho $R \$ 6.915(U \$ S 4.000)$, or $R \$ 576$ (U\$S 366) per month, which is a little more than the Brazilian minimum wage in that year.

According to the statistics of the website, 6o CDs were sent to France; 14 to Spain; 15 to Germany; 68 to the USA; 15 to Australia; and one to Russia.

When I travelled to France for my fieldwork, I took some berimbaus that I had built myself and some of Mestre Waldemar's CDs. Besides helping Master Bigodinho and generating extra income for my fieldwork, the commercial relations that I established with the French angoleiros (who practice Capoeira in the "Angola" style) gave added insight on the increase in value of Brazilian articles made by Brazilian capoeiristas and commercialized in Europe.

I used to sell each one of the CD's for 10 Euros and each berimbau for 80 Euros (most of these articles became gifts for the capoeiristas friends in the places I visited). 
The people I used to sell or give as gifts the berimbaus were, and still are, my friends, or friends of friends. None of the buyers were strangers that would simply make their purchase and then disappear; we had met each other by through networks of capoeristas. After receiving their berimbau or $\mathrm{CD}$, that would often tell me that the reason for buying was to be the owner of an authentic Brazilian berimbau. Others were stimulated to buy because they knew about my research and, mostly, about my relation to Capoeira Angola and the Zimba Group to which I belong. Some of them paid for me to accompany them to the Zimba Group International Meeting of Capoeira Angola, in Santiago da Compostela, to help my Master. Others told me they would like to contribute to my research because they were anxious to read the anthropological work that would result from those journeys.

As Neiburg (2010) has reported, this is about a well-known theme in the Anthropology of Economics: the different meanings of economic transactions. His words are appropriate to my own findings:

[... this is not about underestimating the fact that people separate affection, generosity and indifference to profit. This is about understanding in which conditions such separations are produced and experienced [...] (Neiburg 2010: 10).

I am not therefore interested in advancing a theory of the hostile worlds, where the circulation of money inevitably pollutes social relations of affect. (Zelizer, 1994).

Baptista (2007), analyzing the economical relations within the AfroBrazilian religion of Candomblé distinguishes monetary exchanges between "customers" (people who may consult a religious leader to solve a pressing and momentary problem - clientes) and "sons of saint" (people initiated into the religion - filhos de santo). The "costumers" make "payments", the "sons of saint" offer "help". A "payment" is understood as a simples exchange, in a way that the social relation established through this type of exchange ends as soon as it's performed; on the other hand, an exchange based on "help" acquires a connotation of "gift", and, as such, initiates or contributes to a lasting relationship.

The statement from one of my French interlocutors may serve as a key to understand this issue. When questioned about the reasons why he dedicated himself to the practice of Capoeira Angola, Ciril, a student from GCAC (Group of Capoeira Angola Cabula), answered that Capoeira provides the possibility of 
redeeming the Europeans from the guilt that derives from having been involved in colonization, the slave trade and other forms of exploitation ${ }^{8}$.

I would like to stress that I have no intention of depicting the French angoleiros as a homogenous group nor of suggesting that their behavior is motivated by a search for redemption; in fact there is a moveable relationship between redemption and reparation. In the examples I have given, the idea of reparation is associated to that of guilt, and both may be synthesized in the desire for redemption. In other words, the motivation for reparation is subordinate to the desire for redemption. While the first term implies guilt, the second does not.

In addition I would like to add two caveats. Firstly, as expounded by Heinich, the notion of redemption does not necessarily appear formulated by the individuals themselves; it is a theoretical construct. Secondly, not all French angoleiros are motivated by a desire for redemption nor social and economic reparation. They are a set of people whose motivations for becoming capoeiristas are widely varied.

Ciril is the owner of a shop in the city of Grenoble called Le Local, which operates according to the so-called commerce équitable (fair trade). He buys craft objects from many parts of the world, directly from small producers, paying them a price considered fair, and re-sells them, under the argument that the reparation of France's economic exploitation of the colonized countries can take place through giving value to the commodities from their small producers.

The rodas (circles) of Capoeira Angola (the participants of the ritual of dance/fight of Capoeira stand in a circle) that were considered the most important in the city of Grenoble, and that attracted Capoeira players from the region, took place at the shop Le Local, among products from many parts of the world, including from Brazil. The connection between a commerce équitable and the practice of Capoeira Angola was not consciously expressed; however, both produce a sentiment of redemption and reparation of the

8 The idea of redemption from the colonial past seems to be something present in the European imaginary. When I was in Lyon there was the release of the movie Fleur du Désert, which tells the life story of the model Waris Dirie, from Somalia, who moved to London in search of better life conditions. In a specific part of the film, Waris Dirie needed help to get a passport and one of her new European friends proposes a fake wedding to help her get a permanent visa and tells her: "[...] that is the least we can do to you, after all our ancestors did to your people." 
inequalities between first, second and third worlds. The interesting fact was that, in the shop, there were paintings, clothes, tennis shoes, and artifacts of different kinds, all of them of Brazilian origin, but there was no berimbau on sale. The absence of the berimbau as a product that could be sold at the shop Le Local is related to the fact that the berimbau is the principal symbol of Capoeira. Even though it could be bought from Brazilians for a fair price, it is not made available with the other objects in the shop. That means, the relation that Ciril has established with the Capoeira doesn't seem to allow for the berimbau to be (re)sold as a profit-making commodity.

It would seem then that the act of selling performed by a Brazilian takes on a very different meaning from the act of reselling made by a European (as in the website mentioned above), even if it is established in an environment of "justice and equality" of commerce équitable. The absence of commerce in the commerce équitable of the berimbaus seems to indicate that the nature of reparation or redemption would be prevented by the presence of profit, no matter how small, as is the case with the other objects sold at Le Local. This profitable relation would re-actualize the phenomenon of colonizing exploitation, which is very present in the imaginary of the Capoeira Angola and associated to the idea of hampered freedom. Among the French angoleiros, there is the strong fear of being labeled as a "neocolonizer"; one who exploits Brazil's traditional culture.

The difference between the status of a berimbau and the other objects sold in the shop Le Local doesn't set aside the similarity between small producers and the Capoeira Angola Master, both of whom participants in a dynamic system of exchange in which it makes sense to value those who are seen as victims in an oppressive economic system. I cannot help perceiving myself as an instrument of redemption for my European friends.

Therefore, at the French Capoeira Angola, the fact that the Capoeira Master or an craftsman is a native from a social context that is perceived as the locus of a historical exploitation that hasn't yet been repaired, makes him apt to be the target of humanitarian actions through privileged financial exchanges that that are stimulated by this feeling of redemption. Thus, the more suffering and poverty there is in the life story of a Brazilian Master or craftsman, more value he and his products will have in the eyes of a French Capoeira player: it is the story of the producer that personifies and values the product; the hau of the craftsman or Capoeira Master is what lends value to the berimbau. 
I found that the owners of berimbaus, whenever given the chance, tell of the origin and the craftsman or seller that they bought it from. They are used with extreme care and they are not taken to any roda. When they are taken to rodas outside their usual places, the angoleiros from the GCAC from Lyon transport them in cushioned bags that are made for transporting snow skis, leaving their skis without any protection.

This logic of giving greater value to products connected with a context of poverty and suffering along with traditional knowledge helps understand why Valmir das Biribas, for example, publicizes his orphaned childhood and his relationship with Master Waldemar.

It was this same logic that led the GCAC group in France to get close to Master Barba Branca and not the other internationally known groups. The fact is that Master Barba Branca lives in the suburbs of Salvador and is very poor; his academy has only a few students and no foreigners; there are many poor kids who have free classes and don't even have uniforms. Even in these conditions, the Master didn't ask the French Capoeira players for any "payment", but "gifts" or "help" - that's what immediately captivated them.

Before thinking about a utilitarian logic through which the French capoeiristas would be thinking about saving or buying the best product for the best price, I believe that Master Barba Branca is the model of the ideal Master, who offers the possibility of redemption.

The trajectory of the relation between this Master and disciples went through many transformations. The first approximation with Master Barba Branca was one of "consumers" seeking "service", when he was asked to go to France and was "paid" for his workshop. Soon after that, the French came to Brazil to build a closer connection - they wanted to be able to use the group's shirt, and thus, to represent Master Barba Branca in France.

For this first visit to Brazil in search of belonging, a group of about 15 French capoeiristas organized a "humanitarian action": they collected computers, clothes, food, shoes, school supplies and went to Brazil to stay at the Cabula neighborhood in Salvador, headquarters of the GCAC (Capoeira Angola Cabula Group). There they organized free workshops on dance, computers and school tutoring (since one of them spoke Portuguese very well) for the children in the neighborhood.

After establishing this bond, the invitations for workshops in France were made, and, as a counterpart, financial "help" was given to the Master so 
that his work with the children in the project could be improved. The status of the French disciples ceased to be "clients"; they became "sons of Capoeira".

Tigrão, who was responsible for GCAC nucleus in France at the time, told me that, as soon as he came to Brazil, he looked for Master Moraes's academy (whose renown reaches capoeiristas in the five continents), but he thought everything was too clean and prepared to receive foreign tourists, demanding a high price, in dollar, for their classes - that is, Master Moraes demanded a "payment".

Then, is there a difference between Master Barba Branca and Master Moraes in relation to the way they understand Capoeira Angola?

For the first the relation that exists in Capoeira Angola is not about a possibility of acquisition of a "payment" or selling a commodity; for the second, there is the explicit consciousness that nowadays Capoeira Angola is traded for money, in the form of a "payment".

\section{The commodification of Capoeira as a political standing}

Master Moraes is considered one of the most critical and scathing Capoeira Angola Masters in current days. He has been an activist for the black people's cause in Brazil for many years and defends Capoeira Angola as a weapon from the oppressed against the oppressor, including the proletariat against the bourgeoisie. He was the one responsible for the rise of Capoeira Angola in the 1980's.

In one of his litanies, he writes:

History fools us/ It says everything opposite / It even says abolition happened in the month of May/ The proof of this lie is that I can't get out of misery/ Long live the November $20^{\text {th }} /$ A moment to remember/ I can't see anything to celebrate on May $13^{\text {th }} /$ Many years have passed and the blacks keep fighting/ Zumbi is our hero/ He was the Lord of Palmares/He was the one who fought the most for the black man's cause/ Despite his fight, blacks are not yet free (Master Moraes, CD GCAC Tem Dendê, 2002 - my emphasis).

In this litany, it is said that the freedom offered to the blacks on May $13^{\text {th }}, 1888$ - the official day for the Abolition of Slavery in Brazil - was a lie. According to Master Moraes, the fight for freedom still goes on nowadays and the proof that this fight still goes on is that blacks haven't left misery. 
The freedom that Master Moraes talks about is not spiritual or social, but a freedom associated with economics, the freedom to consume.

In his blog (http://mestremoraes-gcap.blogspot.com/), Master Moraes defends himself from the criticism that suggested and incoherence between his political discourse and the fact that he was using his blog as a retail outlet, charging high prices for his Capoeira:

Anonymous said: this is becoming a Capoeira schoping (sic) mall ... for a Master that talks so much about not making money with art... how much are the CDs? And the t-shirts? (11/07/2009)

Master Moraes replies: To the Anonymous that compared our blog to a schoping mall (I believe he meant a shopping) I inform that I have nothing against people who make money with Capoeira, as long as the product they offer has good quality. About me, who already know the stories of Masters Bimba, Pastinha and others, I have no shame to charge for my work, but I guarantee it is of great quality. Get out of anonymity and come here to check. To avoid being a victim of the "low seasons", and not to have to sell my product cheap, I have a steady job and my own house. Regarding the price of the shirts, we can't say that because we don't sell them. Our shirts mean that the person who is using them belongs to our group. It's like an ID card. That's why we are so careful about them. Our CD's are for sale, yes. About the prices, in spite of their quality, they are very cheap. One of them was even nominated for a Grammy award. (15/07/2009, my emphasis).

Master Moraes's posture, both in his litany and in his blog makes it clear that, along with the acknowledgment of the ancestral Masters there is also the knowledge that they all suffered in life because they were poor and weren't able to make money from their products.

We have to consider that

(...) we live in a time when most human suffering is still the direct result of the lack of goods. There are whole continents, such as Africa, where the vast majority of people desperately need more consumption, more pharmaceuticals, more housing, more transport, more books, more computers (Miller 2007: 38).

Money made through Capoeira, then, is like a key to access a human condition that Masters such as Pastinha, Bimba, Waldemar da Paixão and 
Bigodinho didn't have access to: the freedom of consumption or the "abolition of poverty" (Miller 2007), that would allow them to consume a good hospital, a reasonable house, healthy food, etc.

In this context, freedom of consumption means citizenship, in the sense of having access to rights guaranteed by the constitution; rights that many Brazilians don't have, including many Capoeira Masters.

It is possible to perceive that for Master Moraes money doesn't pollute his relation to the Capoeira Angola's sacredness on the contrary, it is a way to effect the search for freedom that gives meaning to his practice. The commodification of Capoeira Angola, however, doesn't include selling an identity. His group's t-shirt, for instance, is a priceless good - it is the symbol of family belonging, a question of identity, and to acquire the right to use it, something other than a "payment" is required. The commodification of Capoeira is identified as a political strategy that aims at the acquisition of freedom of consumption, so that it won't current Masters of Capoeira Angola will not suffer in the way their predecessors did.

It is with this notion of commodification of Capoeira as a political struggle in search for the freedom of consumption that I now return to the issue of the berimbaus in the $21^{\text {st }}$ century.

In 2008, the Brazilian government, through its Ministry of Culture, acknowledged Capoeira as part of Brazil's immaterial heritage: the "Roda de Capoeira" was written in the "Book of Forms of Expression" and the work of the Capoeira Masters was written in the "Book of Knowledge" (http://www. cultura.gov.br/site/2008/07/10/aviso-de-pauta-32/).

Since then, the Ministry of Culture and the Institute for the National Historical and Artistic Heritage (IPHAN), have been organizing meetings with Masters from all over Brazil to elaborate public policies that contribute to the "preservation of the tradition of Capoeira". One of the actions proposed was to offer retirement payments for the old Masters, which never came about but ended up motivating actions such as the one described above, performed by the virtual community "Master Pastinha".

In 2010, IPHAN organized the Pró-Capoeira project, where Masters met with representatives of the State to press their demands. One of the principle demands from the Capoeira Masters - taking as an example the "Green Seal" from the ecological berimbau - was the regulation in the international market of the berimbaus through the emission of certification seals, by which 
process the Brazilian State would be guarantor for the Brazilian craftsmen and Masters operating within his niche of the foreign market.

After the registering of Capoeira in Brazil a discussion began over the possible registering of Capoeira as Heritage of Humanity as a whole. That startled the Brazilian capoeiristas, who got worried about the competition that already exists between them and the foreign capoeiristas. The idea that the term "Humanity Heritage" would replace the term "Brazilian Heritage" brought about a fear of neocolonialism, as one of the Masters put it on the occasion.

According to the line of thought exposed in this text, the "certification seal" for the berimbau would materially express the structural search for freedom that is found is all discourses related to Capoeira, but a new freedom that is present in a neoliberal context - the freedom of consumption - through the guarantee of exclusivity in a specific market.

Among the capoeiristas that demanded the certification seal, there was the fear that, without it, once more foreigners would appropriate Brazilian wealth. From this perspective, foreigners would come to Brazil, learn how to play Capoeira and to build berimbaus, and then go back to their countries of origin to commercialize the knowledge they had acquired from Brazilian Masters, who, for the most part do not charge for transmitting this knowledge and live in poverty. A Capoeira instructor can make up to 1500 Euros a month teaching around 20 hours a week of Capoeira in a European country.

In this way of seeing things, we have, on one side, French people who are interested in the practice of Brazilian Capoeira due to the fact that this is a way for them to value the knowledge of historically oppressed people, with the possibility of redeeming themselves colonial guilt, and on the other, Brazilian capoeiristas fearful that the foreigner's interest in Capoeira is just one more form of colonial oppression and exploitation.

\section{Consumption: a means and an end towards the search for freedom}

The berimbau wasn't part of the Capoeira practice in the beginning. As time went by, the berimbau came to be identified with Capoeira in such a way that it is now the prime symbol of Capoeira. Such was the identification of this artifact with the Capoeira Masters, that throughout its history, new material elements, such as medals, coins and seals, have been associated to the instrument, as an expression of the values and relations of specific social groups. 
After the 1940's, the berimbau was transformed from an object whose value was based on its use, to an object whose value was determined by commercial exchange, reflecting the changes in Brazilian society. However, this change has not weakened the social relations between the producers and consumers of berimbau. In the peak of globalized commodification, after the 1980's, the relations between capoeiristas are still lived through values of community belonging, and guided by reciprocity.

I conclude by suggesting that the consumption of and in contemporary Capoeira Angola is of importance for the construction of identities in the political arena. The consumption of Capoeira emerges, either as the means, or as an end related to the pursuit of freedom: for the French capoeiristas, to value and consume products related to Brazilian Capoeira is a political means to free themselves from colonial guilt; for the Brazilian Capoeira Masters, the economical power of consumption and of abandoning misery is the goal of their political actions, the basis of their cultural and ancestral values now realized through a desire to participate in the globalized economy.

\section{References}

ABREU, Frede. 2003. O barracão de mestre Waldemar. Salvador: Ed. Zarabatana. ALMEIDA, Renato. 1958. Compêndio de história da música brasileira. 2ª edição. Rio de Janeiro: F. Briguiet e Comp. Editores

APPADURAI, Arjun. 2008. A vida social das coisas: as mercadorias sob uma perspectiva cultural. Rio de Janeiro: EDUFF.

BAPTISTA, José Renato de Carvalho. 2007. "Os deuses vendem quando dão: os sentidos do dinheiro nas relações de troca no candomblé". Mana. Estudos de Antropologia Social, 13(1): 7-40.

BRITO, Celso de. 2011. "A mobilização dos símbolos religiosos na Capoeira: sincretismos e anti-sincretismos". Debates do NER, 19: 53-75p.

BRITO, Celso de. 2010. A roda do mundo: os fundamentos da Capoeira Angola "glocalizada". Master's dissertation in Social Anthropology, Universidade Federal do Paraná.

BRITO, Celso de. 2008. "Identidade e estilo de vida entre angoleiros do Paraná”. In: Anais $32^{\circ}$ Encontro Anual Da ANPOCS, Caxambú. Ms.

BRITO, Celso de; LEWGOY, Bernardo. 2012. "Análise etnográfica de um grupo de Capoeira Angola na cidade de Lyon-França e sua relação com o contexto 
global". Revue Culture-Kairós. 1(1). In press.

CASCUDO, Luís da Câmara. 1969. Dicionário do folclore brasileiro. Rio de Janeiro: Edições de Ouro.

GODBOUT, Jacques. 2002. "Homo donator versus homo oeconomicus" In:

Paulo Henrique Martins (org.), A dádiva entre os modernos. Discussão entre os fundamentos e as regras sociais. Petrópolis: Vozes. 63-97 pp.

HEINICH, Natalie. 1991. "Réparation par l'argent: l'achat et le rachat". In: La gloire de Van Gogh: l'essai de l'anthropologie de l'admiration. Paris: Minuit. pp. 149-167.

KOPYTOFF, Igor A . 2008. "Biografia cultural das coisas: a mercantilização como processo". In: A. Appadurai, A vida social das coisas: as mercadorias sob uma perspectiva cultural. Niterói: EDUFF, pp. 89-121.

MARCUS, George E. 1995. "Ethnography in/of the world system: the emergence of multi-sited ethnography”. Annual Review of Anthropology, 24: 95-117.

MESTRE PASTINHA. 1964. Capoeira Angola. Rio de Janeiro: Ministério da Educação e Cultura.

MILLER, Daniel. 2007. “Consumo como cultura material”. Horizontes Antropológicos, 28: 33-63.

MILLER, Daniel. 1987. Material culture and mass consumption. Oxford: Basil Blackwell.

MILLER, Daniel. 2001. Materials cultures: why some things matter? London: Taylor \& Francis e-Library.

MONJARET, Anne. 1998. "L'argent des cadeaux". Ethnologie Française, 28(4): 493-505.

NEIBURG, Federico. 2010. "Os sentidos sociais da economia". In: L. F. Dias Duarte; C. Benedito Martins (orgs.), Antropologia. Horizontes das ciências sociais no Brasil. São Paulo: Anpocs / Ciência Hoje / Discurso Editorial / Barcarolla. pp. 225-258.

ORTIZ, Fernando. 1955. Los instrumentos de la musica afrocubana. Habana: Ministério da Educación. vol. V.

PINTO, Tiago de Oliveira. 2001. "Som e música: questões de uma antropologia sonora”. Revista de Antropologia, 44(1): 06-11.

REGO, Waldeloir. 1968. Capoeira Angola: ensaio sócio-etnográfico. Salvador: Itapuã.

SANTANA, Tânia. 2007. "O culto aos santos católicos e a escravidão africana 
na Bahia colonial”. Revista Aulas. Dossiê Religião, 4: 01-24.

SANTOS, Teles Jocélio. 2005. O poder da cultura e a cultura no poder. Salvador: Edufba.

SHAFFER, Kay. 1977. O berimbau-de-barriga e seus toques. Rio de Janeiro:

Funarte / Instituto Nacional do Folclore (monografias folclóricas, 2).

ZELIZER, Viviana. 1994. The social meaning of money. New York: Basic.

\section{About the author}

Institution: Department of Anthropology - Universidade Federal do Rio Grande do Sul (UFRGS) - Brazil

Address: Vigário José Inácio, n. 817, ap. 01, CEP: 90020-100, Centro, Porto Alegre, RS, Brazil.

E-mail: celsodebrito@yahoo.com.br

Received May 3, 2012, approved November 30, 2012 